\title{
MONITORING OF LEACHATE QUALITY AT A SELECTED MUNICIPAL LANDFILL SITE IN PODLASIE, POLAND
}

\author{
Izabela Anna Tałałaj', Paweł Biedka', Maria Jolanta Walery' ${ }^{1}$ Jacek Leszczyński² \\ 1 Department of Environmental Engineering Systems, Bialystok University of Technology, ul. Wiejska 45E, \\ 15-351 Bialystok, Poland, e-mail: i.talalaj@pb.edu.pl \\ 2 Department of Technology in Engineering and Environmental Protection, Bialystok University of Technology, \\ ul. Wiejska 45E, 15-351 Bialystok, Poland
}

Received: 2016.03.16 Accepted: 2016.06.01 Published: 2016.07.01

\begin{abstract}
The paper presents an evaluation of leachate monitoring data as well as investigation of temporal and seasonal variability of leachate quality. The analysis includes 27 sampling carried out at selected municipal landfill during 7-year observation period. In leachate samples, concentration of $\mathrm{Pb}, \mathrm{Cu}, \mathrm{Zn}, \mathrm{Cr}, \mathrm{Hg}, \mathrm{Cd}$, Total Organic Carbon (TOC), Polycyclic Aromatic Hydrocarbons (PAH) and value of $\mathrm{pH}$ and electro-conductivity (EC) were determined. Estimation of landfill leachate demonstrated a declining trend in $\mathrm{EC}$, TOC and $\mathrm{Zn}$ concentration with time. Concentration of $\mathrm{Pb}, \mathrm{Hg}, \mathrm{Cr}$, $\mathrm{Cd}$ and $\mathrm{PAH}$ remained relatively constant with respect to the sampling time, however, the value of $\mathrm{pH}$ showed a growing trend due to the decrease of the concentration of the partially ionized free volatile fatty acids. Average concentration of heavy metals in leachate were observed in trace quantities $\left(<1.0 \mathrm{mg} \cdot \mathrm{dm}^{-3}\right)$. There were no statistically significant seasonal variations in concentration of the analyzed parameters, however, the highest concentration of EC, TOC and PAH were observed in summer. The negative correlation of $\mathrm{pH}$ with $\mathrm{Pb}, \mathrm{Cu}, \mathrm{Zn}, \mathrm{Cr}, \mathrm{Hg}, \mathrm{Cd}$ indicated a strong connection of leachate's $\mathrm{pH}$ with heavy metals concentration. A cluster analysis allowed to specify two groups of variables: cluster I with TOC as an indicator of organic pollution in leachate and claster II with the rest of parameters. Further systematic monitoring is necessary, but its scope, according to the author, should be redefined.
\end{abstract}

Key words: leachate, landfill, monitoring, pollution

\section{INTRODUCTION}

The deposition of municipal solid waste in landfills is the most common management alternative in most countries [Kjeldsen et al. 2002, Eurostat 2015]. One of the products which are produced during landfill operation is leachate. They are the result of undergoing physico-chemical and biological changes in landfill body, percolation of rainwater through the wastes and inherent moisture content in the waste [Theepharaksapan et al. 2011, Ahmed and Lan 2012]. Leachate is formed when moisture content of waste exceeds the field capacity, defined as the total amount of moisture that can be retained in a waste sample subject to the downward pull of gravity [Durmusoglu and Yilmaz 2006]. Combined physical, chemical and microbial processes in the waste transfer pollutants from the waste material to the percolating water.

Many factors influence leachate composition including the types of wastes deposited in the landfill, moisture content, the particle size, the hydrology of the site, the climate, and age of the fill, and other site-specific conditions including landfill design or type of liners used [Kumar and Alappat 2005]. However, the biodegrability of organic content in the MSW and compaction of the waste layers make the landfill all anaerobic environment, giving many similarities to the 
composition of leachate between different landfills [Kjeldsen et al. 2002].

According to Christensen et al. [2001], focusing on the common type of landfill receiving a mixture of municipal waste, but excluding significant amounts of concentrated specific chemical waste, landfill leachate may be characterized as a water based solution of four groups of pollutants [Christensen et al. 2001]:

- dissolved organic matter, expressed as Chemical Oxygen Demand (COD) or Total Organic Carbon (TOC), including $\mathrm{CH}_{4}$, volatile fatty acids (in particular in the acid phase of the waste stabilization) and more refractory compounds for example, fulvic-like and humiclike compounds,

- inorganic macrocomponents: $\mathrm{Ca}, \mathrm{Mg}, \mathrm{Na}, \mathrm{K}$, $\mathrm{NH}_{4}^{+}, \mathrm{Fe}, \mathrm{Mn}, \mathrm{Cl}, \mathrm{SO}_{4}^{2-}, \mathrm{HCO}_{3}^{-}$,

- heavy metals: $\mathrm{Cd}, \mathrm{Cr}, \mathrm{Cu}, \mathrm{Pb}, \mathrm{Ni}$ and $\mathrm{Zn}$,

- xenobiotic organic compounds (XOCs) originating from household or industrial chemicals and present in relatively low concentrations in the leachate (usually less than $1 \mathrm{mg} \times \mathrm{dm}^{-3}$ of individual compounds). These compounds include, among others, a variety of aromatic hydrocarbons, phenols and chlorinated aliphatics.

Other compounds may be found in leachate from landfills: e.g. B, As, Se, Ba, Co. But in general they are found in very low concentrations and are not often monitored.

Due to leachate's characterization, they have been identified as one of the major threats to groundwater resources [Mor et al. 2006a]. So the monitoring of leachate is among the most important factors to be considered in planning, design and operation of MSW landfills [Umar et al. 2010]. The landfill monitoring system in Poland is in compliance with the requirements of European Community Directive 99/31/EEC. The immediate objective of this Directive is to establish legal measures and procedures to avoid or minimize harmful environmental impacts associated with waste disposal. Polish regulations concerning leachate monitoring are included in Regulation of Minister of Environment concerning the landfills [Journal of Laws from 30.04.2013]. According to this regulation leachate monitoring should be conducted during time of landfill exploitation and for 30 years after its closure. The parameters which should be obligatory to analyse in leachate from MSW include: $\mathrm{pH}$, electro-conductivity (EC), TOC, Cu, Zn, Pb, Cd, Cr(VI), Hg, Polycy- clic Aromatic Hydrocarbons (PAHs). Frequency of leachate monitoring in accordance with regulations is: every three months for operating landfills and every six months for closed landfills. Although monitoring of landfill leachate is required, it does not work satisfactorily. The main problem of leachate monitoring in Poland is the lack of standards limits to which one could compare the leachate data obtained during monitoring. For the interpretation of the results the standards for discharging wastewater into sewage system [Journal of Laws from 14.07.2006] or standards for putting of wastewater into water and soil. [Journal of Laws from 24.07.2006] are often used. None of these methods is fully adequate, so interpretation of leachate analytical data is difficult and may be not-objective because of the lack of clear standard limits. Another problem is the scope of monitoring, focused mainly on the analysis of heavy metals, which does not fully reflect the degree of leachate contamination and their impact on the environment.

The main objective of the present study is to evaluate leachate data of 7-year monitoring period from selected landfills in Poland. The variability of leachate quality and the direction of the analyzed parameters changes during the study period were determined. Particular attention was paid to seasonal variability of leachate. The relationship between the analyzed parameters were also examined and explained by the use of correlation and cluster analysis.

\section{MATERIAL AND METHODS}

\section{Area of study}

The analyzed landfill is located in southeast part of Podlasie Province, Poland (5303'54.3739'”N, 28 $8^{\circ}$ '49.6621'”E). The climate in this region is continental with close to $50 \%$ rainfall occurring between May and August. The average rainfall is about $550 \mathrm{~mm}$ per year. The average temperature is between $-5^{\circ} \mathrm{C}$ (in January) and $17.3{ }^{\circ} \mathrm{C}$ (in July). The average annual temperature is about $7{ }^{\circ} \mathrm{C}$.

The analyzed landfill is one of the biggest landfill sites in Podlasie and it has been operated since 1981. The total landfill area is 40 ha. The landfill is designed for municipal waste with exception of fluid waste, hazardous substances, radioactive and toxic waste. The total amount of 


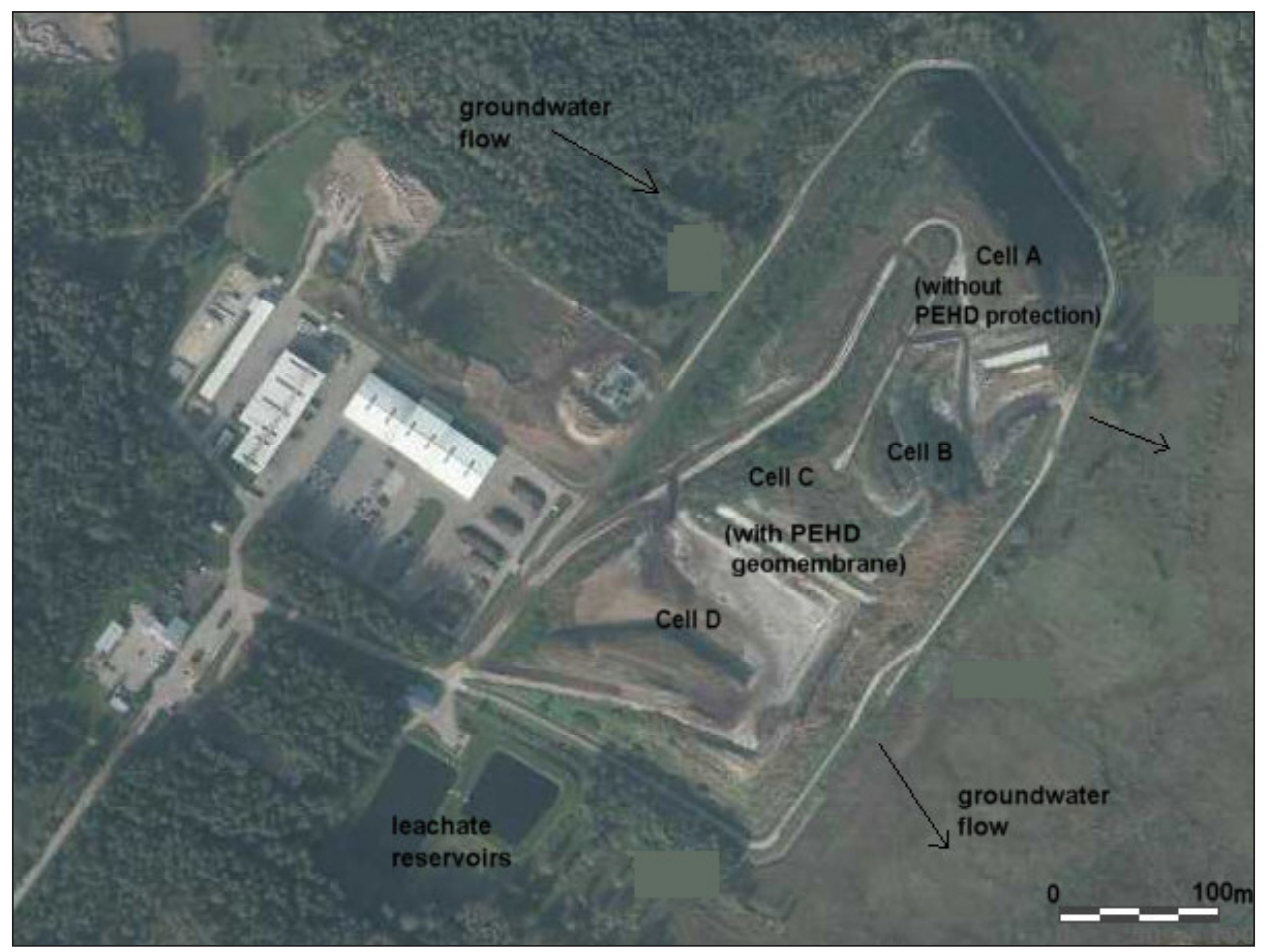

Figure 1. Localization of analyzed landfill site

solid waste deposited in the landfill at the end of 2011 was estimated at $375000 \mathrm{~m}^{3}$. Remaining free capacity is estimated at about $300000 \mathrm{~m}^{3}$, which will deposit about $200000 \mathrm{Mg}$ of waste. The landfill consists of four cells, from which the oldest one-cell A- (closed in 2001) is not equipped with a liner system and is sealed with $50 \mathrm{~cm}$ clay layer to protect groundwater (Figure 1).

The other three other cells are protected with the 2.5-mm-thick geomembrane (PEHD) placed at the bottom. In these cells, the leachate is collected by perforated pipes on top of the liner and flows by gravity to pumping station. Then, pumps transfer the leachate to the retention reservoir. Leachate amount is about $25000 \mathrm{~m}^{3}$ per year.

The area around the landfill is covered by a sand formation, which is underlain by a complex of boulder clay. The free groundwater table lays 0.95 to $5.5 \mathrm{~m}$ below the land surface. The landfill is underwashed on the west side by groundwater that flows down in north-easterly, south-easterly, and easterly directions.

\section{Data analysis}

Leachate samples for analysis were collected according to monitoring regulations - four times a year starting from March 2004 until December 2010. The sample used in this study were collected from the leachate reservoir, then transported to laboratory and stored at $4{ }^{\circ} \mathrm{C}$. The following parameters were monitored: $\mathrm{pH}, \mathrm{EC}, \mathrm{TOC}, \mathrm{Pb}, \mathrm{Cu}$, $\mathrm{Zn}, \mathrm{Cr}, \mathrm{Hg}, \mathrm{Cd}$, PAHs. The analyses were done in commercial and accredited laboratory of Regional Inspectorate of Environmental Protection in Bialystok. Determinations were carried out according to the Polish Standards. $\mathrm{pH}$ was measured using potentiometric method (according to PN90/C-04540-01), EC - using conductivity method (PN-EN27888:1999). The soluble forms of metals were determined in samples filtered through micropore filtres $(\phi=0.45 \mu \mathrm{m})$. Digestion of metals was performed applying microwave digestion system. The heavy metals - except for $\mathrm{Hg}$ - were analyzed by atomic emission spectrophotometry ICP-OES (PN-EN ISO 11885:2009), $\mathrm{Hg}$ was determined by atomic absorption spectrophotometry (PB-IN 4:04.11.2010). TOC was measured with infrared spectrometry method (PN-C-04633-3:1994), PAH - with HPLC method with fluorescence detection (PB-05-78/PAI 2:25.06.2007).

Data analysis included basic statistics (mean, standard deviation, median, minimum, maximum), linear regression of chemical variation vs. time to determine change direction, analysis of variance to determine effect of season on leachate quality. Correlation analyses were performed to show the relationship between the chemi- 
cal parameters and cluster analysis - to classify analyzed parameters.

\section{RESULTS AND DISCUSSION}

\section{Characteristics of landfill leachate}

The characteristic of leachate samples collected from the landfill site during its monitoring in years 2004-2010 has been presented in Table 1 . The table includes also the direction of change with time for each analyzed parameter and the standard limits, which are used in Poland in leachate quality interpretation: $\mathrm{A}$ - standard limits for industrial wastewater discharging into sewerage system (Journal of Laws from 14.07.2006) and B - standard limits that must be met during releasing wastewater into water and soil (Journal of Laws from 24.07.2006).

All values in the table are within the range of leachate quality data presented in literature [Bocanegra et al. 2000, Kjeldsen and Christophersen 2001, Tatsi and Zouboulis 2002, Al.-Yaqout and Hamoda 2003, Renou et al. 2008, Abbas et al. 2009]. The $\mathrm{pH}$ of leachates was in the range 7.18.6 , with mean value of 8.1. According to Długosz [2012] and Kulikowska and Klimiuk [2008] pH of leachate increase with time due to the decrease of the concentration of the partionally ionized free volatile fatty acids. In the methanogene phase, the increasing number of methane bacteria results in a net utilization of intermediate products. During study period the value of $\mathrm{pH}$ was within acceptable limits for wastewater introduced into water and soil. The average EC value of the collected samples was found to be $15.20 \mathrm{mS} \cdot \mathrm{cm}^{-1}$, which is relatively not very high. In Poland, there is no standard limits for this parameter in wastewater. One of the parameters, which are used to describe the content of dissolved organic matter in leachate, is TOC. A typical concentration range of TOC in MSW landfill leachate is 30-30 000 $\mathrm{mg} \cdot \mathrm{dm}^{-3}$ [Kjeldsen et al. 2002]. the results in the table show that the monitored leachate had a low organic content and the highest TOC concentration in the analyzed leachate did not achieve 5500 $\mathrm{mg} \cdot \mathrm{dm}^{-3}$. However this value exceeds the Polish standard limit for wastewater introduced into water and soil, which is $30 \mathrm{mg} \cdot \mathrm{dm}^{-3}$.

The highest $\mathrm{Pb}, \mathrm{Cu}, \mathrm{Zn}, \mathrm{Hg}$ and $\mathrm{Cd}$ concentration in the analyzed leachate did not exceed $1 \mathrm{mg} \cdot \mathrm{dm}^{-3}$. Only $\mathrm{Cr}(\mathrm{VI})$ concentration reached its maximum of $1.87 \mathrm{mg} \cdot \mathrm{dm}^{-3}$, although its mean was not high $-0.32 \mathrm{mg} \cdot \mathrm{dm}^{-3}$. The presence of $\mathrm{Zn}$ in leachate shows, that landfill receives waste from batteries and fluorescent lamp. The presence of $\mathrm{Pb}$ in the leachate samples indicates probably the disposal of $\mathrm{Pb}$ batteries, chemicals for photograph processing, $\mathrm{Pb}$-based paints [Mor et al. 2006a, Mor et al. 2006b, Moturi et al. 2004]. So, the reason for the low concentration of heavy metals in analyzed leachate is not a lack of heavy metals present in waste. Heavy metal balances for landfills have shown that less than $0.02 \%$ of heavy metals received at landfills are leached from the

Table 1. Basic statistic of analyzed leachate with its trend of change direction

\begin{tabular}{|c|c|c|c|c|c|c|c|c|c|}
\hline \multirow{2}{*}{ Parameter } & \multirow{2}{*}{$\mathrm{N}$} & \multirow{2}{*}{ Mean } & \multirow{2}{*}{ Median } & \multirow{2}{*}{ Min } & \multirow{2}{*}{ Max } & \multirow{2}{*}{$\begin{array}{l}\text { Stand. } \\
\text { deviat. }\end{array}$} & \multirow{2}{*}{$\begin{array}{l}\text { Direction } \\
\text { of change }\end{array}$} & \multicolumn{2}{|c|}{ Standard limits } \\
\hline & & & & & & & & A & B \\
\hline $\mathrm{pH}$ & 27 & 8.11 & 8.16 & 7.12 & 8.65 & 0.32 & $\uparrow$ & - & $6.5-9.0$ \\
\hline EC & 27 & 15.19 & 6.29 & 25 & 29.80 & 8.10 & $\downarrow$ & - & - \\
\hline TOC & 26 & 978.5 & 65.5 & 78.2 & 5491.5 & 1159.9 & $\downarrow$ & - & 30 \\
\hline $\mathrm{Pb}$ & 27 & 0.063 & 0.050 & 0.003 & 0.200 & 0.062 & $\sim$ & 1.0 & 0.5 \\
\hline $\mathrm{Cu}$ & 27 & 0.095 & 0.073 & 0.006 & 0.363 & 0.092 & $\sim$ & 1.0 & 0.5 \\
\hline $\mathrm{Zn}$ & 27 & 0.355 & 0.322 & 0.006 & 0.912 & 0.207 & $\downarrow$ & 5.0 & 2.0 \\
\hline $\mathrm{Cr}(\mathrm{VI})$ & 25 & 0.320 & 0.016 & 0.001 & 1.874 & 0.524 & $\sim$ & 0.2 & 0.1 \\
\hline $\mathrm{Hg}$ & 26 & 0.003 & 0.001 & 0.0002 & 0.021 & 0.005 & $\sim$ & 0.03 & 0.03 \\
\hline $\mathrm{Cd}$ & 27 & 0.012 & 0.003 & 0.0005 & 0.063 & 0.015 & $\sim$ & 0.2 & 0.2 \\
\hline $\mathrm{PAH}$ & 27 & 0.251 & 0.060 & 0.002 & 2.650 & 0.635 & $\sim$ & 0.2 & - \\
\hline
\end{tabular}

A - standard limits according to Regulation of Minister of Building concerning the obligations of supplier of industrial wastewater and the conditions for discharging wastewater into sewerage system (Journal of Laws from 14.07.2006).

B - standard limits according to Regulation of Minister of Environment concerning the conditions that must be met during the putting of wastewater into water and soil (Journal of Laws from 24.07.2006).

Concentration change with time: $\uparrow$ increase, $\downarrow$ decrease, $\sim$ stable

All in $\mathrm{mg} \cdot \mathrm{dm}^{-3}$ except $\mathrm{EC}\left(\mathrm{mS} \cdot \mathrm{cm}^{-1}\right) \downarrow$ and $\mathrm{pH}$ 
landfill after 30 years [Øygard et al. 2004, Liu and Sang 2010]. Analyzed heavy metals - except the $\mathrm{Cr}(\mathrm{VI})$ - do not exceed the Polish standard limits. Both sorption and precipitation are believed to be a significant mechanism for metal immobilization [Christensen et al. 2001, Kjeldsen et al. 2002, Øygard et al. 2004]. Slightly higher metal concentration are stated only in leachate from young landfills because of high degree of metal solubilization as a result of low $\mathrm{pH}$ caused by the production of organic acids [Statom et al. 2004]. Cr(VI) is highly soluble and the most mobile form of migration of this element. Increased concentrations of $\mathrm{Cr}$ in the leachate may come from the stored waste from tanneries, dyeing and electroplating.

PAHs are one of the Xenobiotic Organic Compounds (XOCs) which are most frequently found in landfill leachate [Kjeldsen et al. 2002, Jiries et al. 2005]. The value of PAH in leachate from analyzed landfill varied from $0.002 \mathrm{mg} \cdot \mathrm{dm}^{-3}$ to $2.65 \mathrm{mg} \cdot \mathrm{dm}^{-3}$, with mean value of $0.25 \mathrm{mg} \cdot \mathrm{dm}^{-3}$. PAH standard limit for wastewater discharging into sewage system is $0.2 \mathrm{mg} \cdot \mathrm{dm}^{-3}$. There were observed two peaks with value exceeding the standard limit for wastewater, which occurred in time of highest precipitation: in June 2006 and September 2008. Despite this, the concentration of PAH can be taken as stabile during seasons and years.

\section{Temporal and seasonal variation}

The variation in chemical composition of leachate for the period from March 2004 to December 2010 is shown in Figure 2 and Figure 3.

The evaluation of temporal trends is based on the slope of linear regression between time and concentration of each analyzed parameter. Table 1 lists the trend as either increasing $(\uparrow)$, decreasing $(\downarrow)$ or stable $(\sim)$, depending on the value and slope of regression line.

Values of $\mathrm{pH}$ were relatively constant with low increase tendency. Effect of $\mathrm{pH}$ on the mobility of heavy metals was evident in 2009, when the increase in $\mathrm{pH}$ caused a decrease in the concentration of $\mathrm{Pb}, \mathrm{Cd}, \mathrm{Hg}$ and $\mathrm{Cd}$ in the leachate. Value of conductivity showed great differences than $\mathrm{pH}$. As time goes, its value decreased from 17.02 $\mathrm{mS} \cdot \mathrm{cm}^{-1}$ (mean value in 2004) to $7.38 \mathrm{mS} \cdot \mathrm{cm}^{-1}$ (mean value in 2010). The highest values of conductivity are achieved during the summer months (mean value for June is $18.69 \mathrm{mS} \cdot \mathrm{cm}^{-1}$ ) and the lowest in spring (mean value for March - 12.96 $\left.\mathrm{mS} \cdot \mathrm{cm}^{-1}\right)$. This may be due to higher precipitation in summer and leaching from waste a number of soluble minerals. About $12 \%$ of percolation in Poland falls on May, and 22\% - on May and June. The highest concentration of TOC was recorded in $2004-549 \mathrm{mg} \cdot \mathrm{dm}^{-3}$. TOC concentration decreases over time, which is result of organic matter decomposition and its weight and volume loss in the waste. The highest concentration of TOC, exceeding of $1000 \mathrm{mg} \cdot \mathrm{dm}^{-3}$, falls on June and slightly lower - on September. As in the case of conductivity, it is due to both higher values of rainfall in this period and intensified degradation processes of organic matter which is a result of temperature increases in summer months.

The metals: $\mathrm{Pb}, \mathrm{Cu}, \mathrm{Cr}, \mathrm{Cd}, \mathrm{Hg}$ all displayed relatively stabile trend (Figure 3 ). Concentration of all heavy metals are low because landfilled waste, especially at the neutral or above neutral $\mathrm{pH}$ values, has significant sorptive capacity and enhances metal hydroxide precipitation

Table 2. The mean value of monitored parameters in each season of the year and results of variance analysis

\begin{tabular}{|c|c|c|c|c|c|c|c|c|c|c|c|}
\hline Month & $\mathrm{pH}$ & $\mathrm{EC}$ & $\mathrm{TOC}$ & $\mathrm{Pb}$ & $\mathrm{Cu}$ & $\mathrm{Zn}$ & $\mathrm{Cr}(\mathrm{VI})$ & $\mathrm{Hg}$ & $\mathrm{Cd}$ & $\mathrm{PAH}$ \\
\hline March & 8.04 & 12.96 & 697.5 & 0.074 & 0.114 & 0.442 & 0.452 & 0.007 & 0.023 & 0.077 \\
\hline June & 8.13 & 18.69 & 1483.9 & 0.062 & 0.047 & 0.366 & 0.304 & 0.001 & 0.009 & 0.455 \\
\hline September & 8.26 & 13.81 & 1002.8 & 0.069 & 0.110 & 0.340 & 0.397 & 0.002 & 0.009 & 0.385 \\
\hline December & 7.99 & 15.33 & 641.5 & 0.045 & 0.110 & 0.259 & 0.114 & 0.002 & 0.007 & 0.059 \\
\hline All in $\mathrm{mg} \cdot \mathrm{dm}^{-3}$ except EC $\left(\mathrm{mS} \cdot \mathrm{cm}^{-1}\right.$ ) and pH \\
\hline SS & 0 & 134 & $2.9^{*} 10^{6}$ & 0 & 0 & 0 & 0 & 0 & 0 & 1 \\
\hline df & 3 & 3 & 3 & 3 & 3 & 3 & 3 & 3 & 3 & 3 \\
\hline MS & 0.1 & 44.8 & 982317 & 0.0 & 0.0 & 0.0 & 0.1 & 0.0 & 0.0 & 0.3 \\
\hline F & 0.926 & 0.655 & 0.704 & 0.241 & 0.829 & 0.842 & 0.456 & 2.376 & 1.747 & 0.677 \\
\hline p & 0.44 & 0.59 & 0.56 & 0.87 & 0.49 & 0.48 & 0.72 & 0.10 & 0.19 & 0.57 \\
\hline
\end{tabular}

SS - sum of squares between groups; df - degree of freedom; MS - mean squares between groups; F - value of test F; $\mathrm{p}$ - probability level 

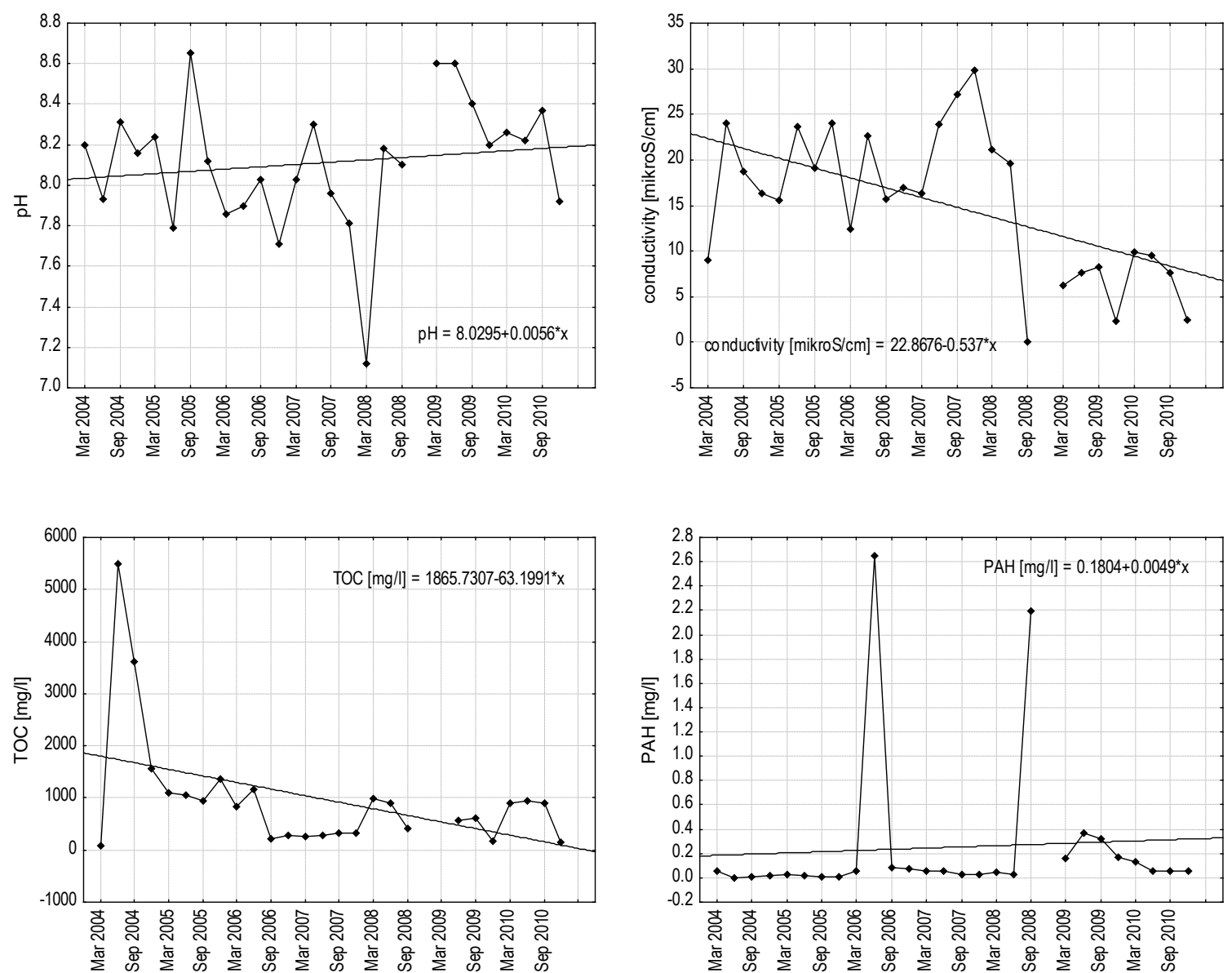

Figure 2. pH and EC value and TOC, PAH concentration in leachate vs. time

[Calabro et al. 2010]. Sorption and precipitation are belived as a main process in metal immobilization [Christensen et al. 2001, Kjeldsen et al. 2002]. With time, moderate to high molecular weight humic-like substances are formed from waste organic matter. These substances tend to form strong complex compounds with heavy metals, which explains stable metal concentrations in the leachate. Release of $\mathrm{Zn}$ shows the most unstable trend compared to another metals. According to Øygard et al. [2004] Zn deponed in waste is partly mobilized by washout and partly by the equilibrium that would be present between the dissolved/complexed metals and precipitated matter. Besides, a substantial part of $\mathrm{Zn}$ seems to be related to inorganic colloids, what makes $\mathrm{Zn}$ more mobile than other metals [Christensen et al. 2001].

The analyses of PAH shown two peaks of concentration: in June $2006-2.65 \mathrm{mg} \cdot \mathrm{dm}^{-3}$ and in September $2008-2.19 \mathrm{mg} \cdot \mathrm{dm}^{-3}$. This high concentration of PAH in leachate may come from intensive infiltration and pollutants leaching from waste body at time of high rainfall as well as from washing out from the road pavement contamina- tion coming from car exhausts, from wearing off car tire, and from asphalt rich in hydrocarbon fractions, which all next can flow along with surface run-offs into open leachate reservoir.

The evaluation of seasonal variation was made with use of variation analysis, which results are resented in Table 2. Obtained data have shown that there is no statistically significant difference in observed concentration of analyzed parameters in each season of year. However, the concentration of analyzed parameters differs in each part of the year. Value of PAHs, EC and TOC increased in June (summer), while concentration of $\mathrm{Pb}, \mathrm{Cu}$, $\mathrm{Zn}, \mathrm{Cr}(\mathrm{VI}), \mathrm{Hg}$ and $\mathrm{Cd}$ was relatively stable during the year. Mobility and migration of heavy metals is reduced by the sorption by organic matter. Heavy metals may also be submitted to sorption by hydrated oxides of $\mathrm{Fe}$ and $\mathrm{Mn}$, as well as undergo precipitation, especially in the presence of sulfide ions [Christensen et al. 2001, Kjeldsen and Christophersen 2001, Kjeldsen et al. 2002, Øygard et al.. 2004]. The highest concentration of TOC in June is caused by higher temperature, which may intensify the process of biodegradation. The value of EC and PAH increase in sum- 

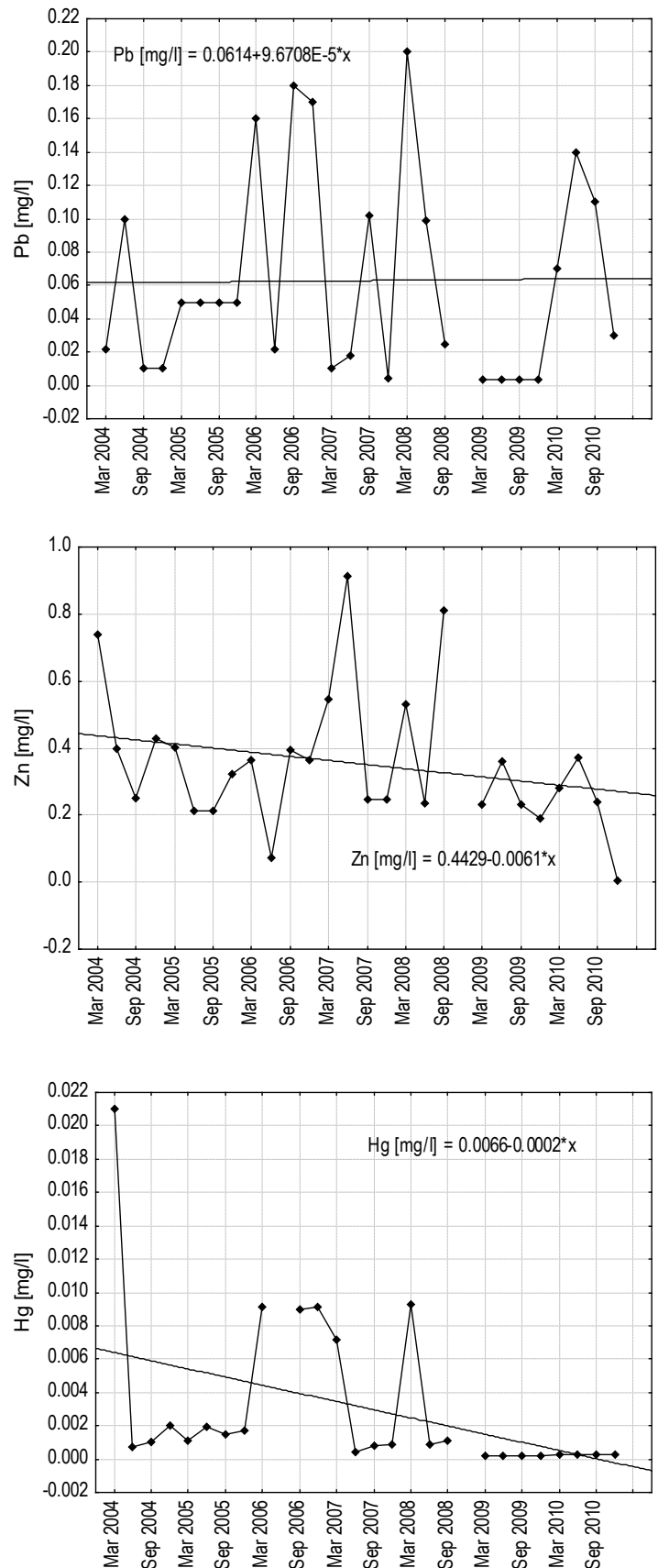
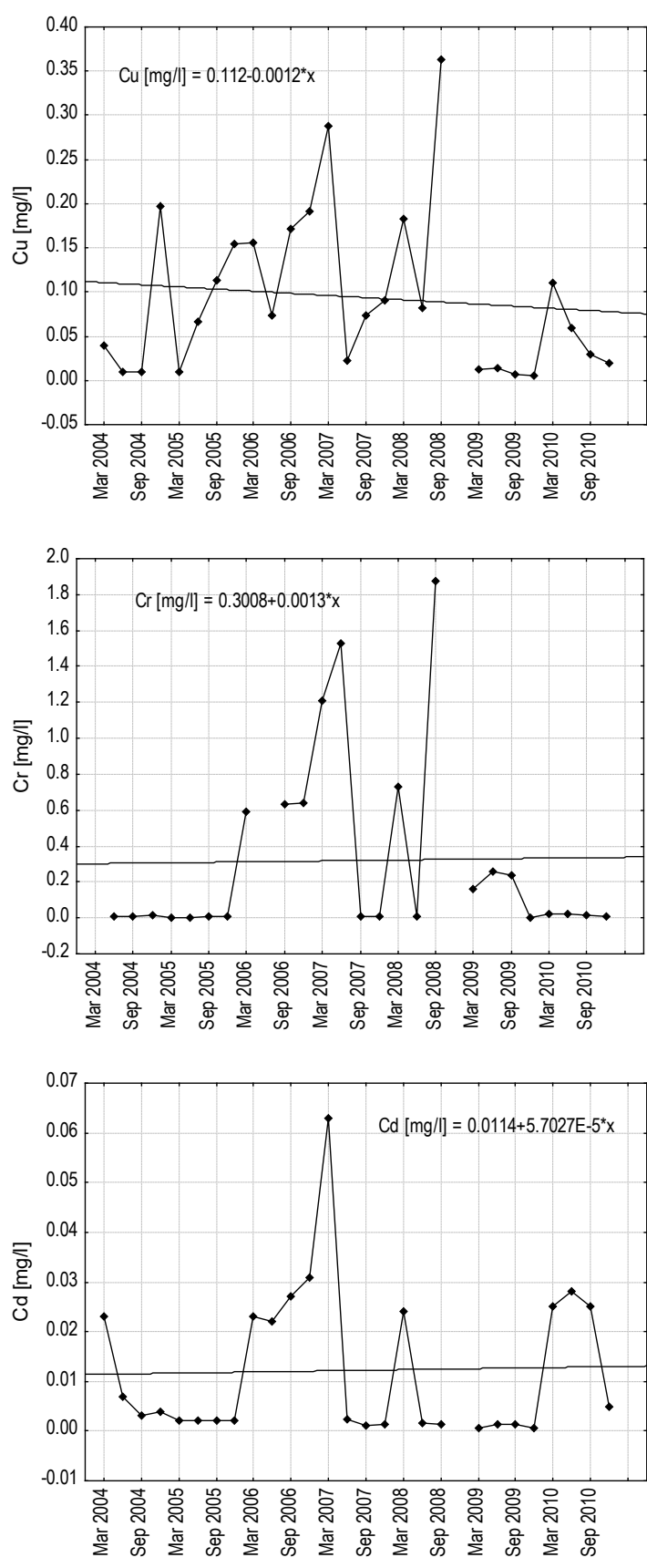

Figure 3. Heavy metals $(\mathrm{Pb}, \mathrm{Cu}, \mathrm{Zn}, \mathrm{Cr}, \mathrm{Hg}, \mathrm{Cd})$ concentration in leachate vs. time

mer, i.e. in time of higher rainfalls which favor pollutants leaching from waste body and stepping up surface run-offs.

\section{Correlation and cluster analysis}

Correlation analysis is a preliminary descriptive technique to estimate the degree of association among the variables involved [Mor et al. 2006a]. Such association is likely to lead to reasoning about relationship between the variables. Correlation matrix between analyzed parameters is shown in Table 3.
Some parameters were found to bear statistically significant correlation with each other indicating close association of these parameters. $\mathrm{Pb}$ had a positive correlation with $\mathrm{Hg}$, which suggests a similar chemical behavior and similar source of these metals. Both of these metals are specific for road runoff, which contains $\mathrm{Pb}$ (from vehicle exhaust) and $\mathrm{Hg}$ (from the abrasion of car tires). From Figure 3 it is seen that the highest concentration of $\mathrm{Pb}$ and $\mathrm{Hg}$ occured in time of spring meltdown, which means, that at this time contamination accumulated in the snow during winter time get into the leach- 
Table 3. Correlation matrix for analyzed leachate parameters

\begin{tabular}{|c|c|c|c|c|c|c|c|c|c|c|}
\hline Parametr & $\mathrm{pH}$ & $\mathrm{EC}$ & $\mathrm{TOC}$ & $\mathrm{Pb}$ & $\mathrm{Cu}$ & $\mathrm{Zn}$ & $\mathrm{Cr}(\mathrm{VI})$ & $\mathrm{Hg}$ & $\mathrm{Cd}$ & $\mathrm{PAH}$ \\
\hline $\mathrm{pH}$ & 1.00 & & & & & & & & & \\
\hline $\mathrm{EC}$ & -0.32 & 1.00 & & & & & & & & \\
\hline $\mathrm{TOC}$ & 0.01 & 0.20 & 1.00 & & & & & & & \\
\hline $\mathrm{Pb}$ & $-\mathbf{0 . 5 3}$ & 0.14 & 0.01 & 1.00 & & & & & & \\
\hline $\mathrm{Cu}$ & -0.34 & -0.06 & -0.26 & 0.19 & 1.00 & & & & & \\
\hline $\mathrm{Zn}$ & -0.09 & 0.06 & -0.04 & 0.02 & 0.48 & 1.00 & & & & \\
\hline $\mathrm{Cr}(\mathrm{VI})$ & -0.17 & -0.16 & -0.30 & 0.03 & $\mathbf{0 . 6 3}$ & $\mathbf{0 . 8 6}$ & 1.00 & & & \\
\hline $\mathrm{Hg}$ & $-\mathbf{0 . 6 1}$ & 0.14 & -0.18 & $\mathbf{0 . 6 5}$ & 0.56 & 0.22 & 0.39 & 1.00 & & \\
\hline $\mathrm{Cd}$ & -0.27 & -0.10 & -0.17 & 0.43 & 0.46 & 0.18 & 0.31 & $\mathbf{0 . 6 4}$ & 1.00 & \\
\hline $\mathrm{PAH}$ & 0.08 & -0.51 & -0.16 & -0.20 & $\mathbf{0 . 5 2}$ & 0.47 & $\mathbf{0 . 6 1}$ & -0.12 & -0.16 & 1.00 \\
\hline
\end{tabular}

The values with significant level $p<0.05$ are highlighted

ate reservoirs together with surface runoff from landfill area. A positive correlation between $\mathrm{Cu}$, $\mathrm{Cr}(\mathrm{VI}), \mathrm{Zn}$ and PAH was also observed. The predominant sources of PAHs are vehicle emissions and atmospheric deposition. According to the Sun et al. [2014] wastewater contamined with PAH were frequently reported to contain high amount of heavy metals, especially $\mathrm{Cu}$ and $\mathrm{Cr}$. The combination of these contaminants is a result of common source of PAH's and heavy metals and adsorption of metals and organic compounds on small organic particles [Lau and Stenstrom 2005]. Simultaneous accumulation of $\mathrm{Cu}, \mathrm{Cr}, \mathrm{Zn}$ and PAHs is also typical for smelting sites and results from sharing the same chemical environment or absorptive pathways by the elements/compounds [Afiukwa 2013, Sun et al. 2014]. The obtained results support these findings. The negative correlation of $\mathrm{pH}$ with $\mathrm{Hg}$, $\mathrm{Pb}$ and slightly weaker negative correlation with $\mathrm{Cu}, \mathrm{Cd}, \mathrm{Zn}$ and $\mathrm{Cr}$ indicate a strong connection of leachate's $\mathrm{pH}$ with concentration of heavy metals. Decrease of $\mathrm{pH}$ intensifies solubility of selected metals. Metals that form the cations $\mathrm{Hg}, \mathrm{Cu}, \mathrm{Cd}, \mathrm{Zn}, \mathrm{Pb}$ - are more mobile with the lowering of $\mathrm{pH}$, in contrast to elements (As, B, Mo, P) forming anions and complexes, which solubility decrease with decrease of $\mathrm{pH}$ [KabataPendias i Pendias 1999].

The above-mentioned interdependence is confirmed by the results of cluster analysis, which was used to classify the studied variables in such a way, that the degree of variables relationship in the same group was the largest. Ward's agglomeration method was used for connection of variables and Euclidean distance for a measure of distance.
The conducted analysis allowed to distinguish two clusters (groups) of variables: cluster I with TOC as a indicator of organic pollution in leachate and cluster II with the rest of parameters. Inside cluster (group) II we can isolate three subgroup:

- IIA - with $\mathrm{Pb}$ and $\mathrm{Hg}$ negatively correlated with $\mathrm{pH}$, low $\mathrm{pH}$ values cause an increase in the mobility of $\mathrm{Pb}$ and $\mathrm{Hg}$;

- IIB - with $\mathrm{Cd}, \mathrm{Cu}, \mathrm{Zn}, \mathrm{Cr}$ positively correlated with each other and behaving similarly in different environmental conditions;

- IIC - with EC and PAH as a general indicator of leachate pollution.

The result of the analysis indicate that for the stabilized landfills, in methanogenic phase, it could be reasonable to limit the number of analyzed heavy metals. Example of heavy metals situated close to each other in one cluster are: $\mathrm{Pb}, \mathrm{Hg}$ from subgroup IIA and $\mathrm{Cd}, \mathrm{Cu}, \mathrm{Zn}$, $\mathrm{Cr}(\mathrm{VI})$ from subgroup IIB. The question is, if for a long time operated landfill, in methanogenic phase with a high value of $\mathrm{pH}$, is reasonable to analyze the concentration of six heavy metals. Especially that some of them show a strong correlation between each other. It should be reasonable to consider replacing the determination of

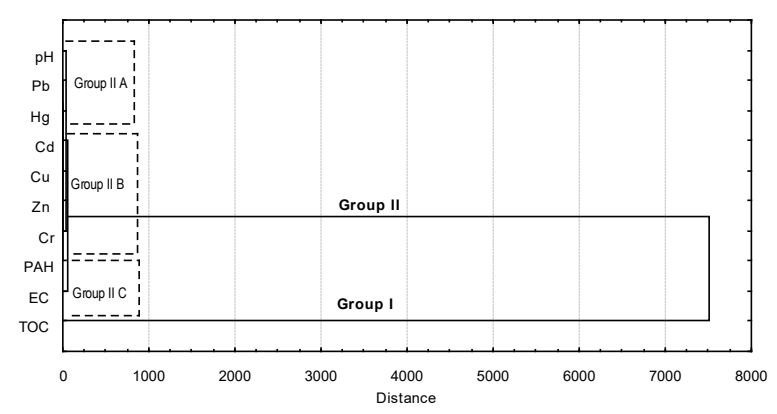

Figure 4. Cluster analysis 
heavy metals by other analysis, providing more valuable information about the leachate quality, the stage of waste decomposition as well as the leachate impact on environment.

\section{CONCLUSIONS}

The study presents results of leachate quality data from seven years of its monitoring. The high value of $\mathrm{pH}$, low TOC and EC value and low heavy metals concentration pointed out that the landfill is in methanogenic stage. The average concentration of most analyzed parameters does not exceed standards limits for wastewater discharging into sewage system and for water putting into water and soil. Exception is TOC and $\mathrm{Cr}(\mathrm{VI})$, which concentration surpass permissible standards. Results for the EC, TOC and $\mathrm{Zn}$ indicate a decrease in concentration, with time, while the rest of analyzed heavy metals and PAH remained stable during the sampling period.

There was no observed statistically significant seasonal variation of the analyzed parameters during the 7-year study period, however the highest concentration of EC, TOC and PAH were observed in summer. Correlation analysis indicated a strong association between $\mathrm{Cu}$ and $\mathrm{Hg}, \mathrm{Cr}(\mathrm{VI}), \mathrm{PAH}$. It also pointed the negative correlation between $\mathrm{pH}$ and the heavy metals concentration in the leachate. The cluster analyzes has specified two groups of analyzed variables: group I with TOC as a indicator of organic pollution in leachate and group II with all heavy metals. The metals situated close to each other in one cluster are: $\mathrm{Pb}, \mathrm{Hg}$ from group IIA and $\mathrm{Cd}, \mathrm{Cu}, \mathrm{Zn}, \mathrm{Cr}(\mathrm{VI})$ from group IIB. Although, the concentration of most analyzed contaminants do not exceed the literature value, the further systematic monitoring is necessary, but its scope, according to the author, should be redefined.

\section{Acknowledgements}

The study was realized during scientific project No. S/WBiIS/02/2014 supported by Polish Ministry of Science and Higher Education. The authors wish also to thank Inspectorate of Environmental Protection in Bialystok for help in data gathering.

\section{REFERENCES}

1. Afiukwa J.N. 2013 Evaluation and correlation study of heavy metals load in drinking water and update of water-related disease in Ebonyi State from 20012011. American Journal of Scientific and Industrial Research, doi:105251/ajsir.2013.4.2.221.225

2. Abbas A.A., Jingsong G., Ping L.Z., Ya P.Y., Al.Rekabi W.S. 2009. Review on landfill leachate treatments. J Applied Sci Res. 5(5), 534-545.

3. Ahmed F.N., Lan C.Q. 2012.Treatment of landfill leachate using membrane bioreactors: A review. Desalination 287, 41-54.

4. Al.-Yaqout A.F., Hamoda M. 2003. Evaluation of landfill leachate in arid climate-case study. Environ Int. 29(5), 593-600.

5. Bocanegra E., Massone H., Martinez D., Civit E., Farenga M. 2001. Groundwater contamination: risk management and assessment for landfills in Mar del Plata, Argentina. Environ Geol. 40(6), 732-741.

6. Calabrò P.S., Sbaffoni S., Orsi S., Gentili E., Meoni C. 2010. The landfill reinjection of concentrate leachate: Findings from a monitoring study at an Italian site. J Hazard Mater. 181, 962-968.

7. Christensen T. H., Kjeldsen P., Bjerg P.L., Jensen D.L., Christensen B.J., Baun A., Albrechtsen H., Heron, G. 2001. Biogeochemistry of landfill leachate plumes. Appl. Geochem.16, 659-718.

8. Długosz J. 2012. Characteristics of the composition and quantity of leachate from municipal landfills - a reviev. Arch Waste Manage Environ Protect. 14(4), 19-30.

9. Durmusoglu E., Yilmaz C. 2006. Evaluation and temporal variation of raw and pre-treated leachate quality from an active solid waste landfill. Water Air Soil Poll. 171, 359-382.

10. Eurostat 2015. http:/ec.europa.eu/eurostat/ $\operatorname{tgm} /$ refreshTableAction.do? tab=table \&plugin= $1 \&$ pcode $=$ tsdpc $240 \&$ language $=$ en (access date: 4.01.2016)

11. Jiries A., Rimawi O., Lintelmann J., Batarseh M. 2005. Polycyclic Aromatic Hydrocarbons (PAH) in Top Soil, Leachate and Groundwater from Ruseifa Solid Waste Landfill, Jordan. Int J Environ Pollut. 23(2), 179-188.

12. Kabata-Pendias A., Pendias H. 1999. Biogeochemia pierwiastków śladowych. PWN, Warszawa.

13. Kjeldsen P., Barlaz M.A, Rooker A.P., Baun A., Ledin A., Christensen, T. 2002. Present and LongTerm Composition of MSW Landfill Leachate: A Review. Crit Rev Env Sci Technol. 32(4), 297-336.

14. Kjeldsen P., Christophersen M. 2001. Composite of leachate from old landfills in Denmark. Waste Manage Res. 19(3), 249-256. 
15. Kulikowska D., Klimiuk E. 2008. The effect of landfill age on municipal leachate composition. Bioresource Technol. 99, 5961-5985.

16. Kumar D., Alappat, B. J. 2005. Evaluating leachate contamination potential of landfill sites using leachate pollution index. Clean Technol. Envir. 7(3), doi: 10.1007/s10098-004-0269-4

17. Lau S-L., Stenstrom M.K. 2005. Metals and PAH adsorbed to street particles. Water Research 39(17), 4083-4092.

18. Liu H.H., Sang S.X. 2010. Study on the law of heavy metal leaching in municipal solid waste landfill. Environ Monit Assess. 165, 349-363.

19. Mor S., Ravindra K., Dahiya R.P., Chandra, A. 2006a. Leachate characterization and assessment of groundwater pollution near municipal solid waste landfill site. Environ Monit Assess. 118, 435-456.

20. Mor S., Ravindra K., Vischler A., Dahiya R.P., Chandra A. 2006b. Municipal solid waste characterization and its assessment for potential methane generation: A case study. Sci. Total Environ. 371(1-3), 1-10.

21. Moturi M.C.Z., Rawat M., Subramanian V. 2004. Distribution and fractionation of heavy metals in solid waste from selected sites in the industrial belt of Delhi, India. Environ Monit Assess. 95, 183-199.

22. Øygard J.K., Måge A., Gjengedal E. 2004 Estimation of the mass-balance of selected metals in four sanitary landfills in Western Norway, with emphasis on the heavy metal content of the deposited waste and the leachate. Water Res. 38, 2851-2858.

23. Regulation of Minister of Building concerning the obligations of supplier of industrial wastewater and the conditions for discharging waste- water into sewerage system. Journal of Laws from 14.07.2006

24. Regulation of Minister of Environment concerning the conditions that must be met during the putting of wastewater into water and soil. Journal of Laws from 24.07.2006.

25. Regulation of Minister of Environment concerning the landfills. Journal of Laws from 30.04.2013.

26. Renou S., Givaudan J.G., Poulain S., Dirassouyan F., Moulin P. 2008. Landfill leachate treatment: review and opportunity. J Hazard Mater. 50(3), 468-493.

27. Statom R.A., Thyne G.D., McCray J.E. 2004. Temporal changes in leachate chemistry of municipal solid waste landfill cell in Florida, USA. Environ Geol. 45(7), 982-991.

28. Sun L., Liao X., Yan X., Zhu G., Ma D. 2014. Evaluation of heavy metal and polycyclic aromatic hydrocarbons accumulation in plants from typical industrial sites: potential candidate in phytoremediation for co-contamination. Environ Sci Pollut Res, doi:10.1007/s11356-014-3171-6.

29. Tatsi A.A., Zouboulis A.I. 2002. A field investigation of the quantity and quality of leachate from municipal solid waste landfill in a Mediterranean climate (Thessalonica, Greece). Adv Environ Res. 6(3), 207-219.

30. Theepharaksapan S., Chiemchaisri C., Chiemchairi W., Yamamoto K. 2011. Removal of pollutants and reduction of bio-toxicity in a full scale chemical coagulation and reverse osmosis leachate treatment system. Bioresource Technol. 102, 5381-5388.

31. Umar M., Aziz H.A., Yusoff M.S. 2010. Variability of parameters involved in leachate pollution index and determination of LPI from four landfill in Malaysia. Int J Chem Eng. doi:10.1155/2010/747953. 